\title{
ANALISIS SEMIOTIKA SOSIAL PEMBERITAAN KASUS KORUPSI E-KTP DI SITUS LIPUTAN6.COM
}

\author{
Oleh: \\ AYU KUMALA SARI, SAPTA SARI, BAYU RISDIYANTO \\ Program Studi Ilmu Komunikasi Fakultas Ilmu-Ilmu Sosial \\ Universitas Dehasen Bengkulu
}

\begin{abstract}
This research is motivated by the E-KTP corruptionnewscases reported by Liputan6.com, in reporting cases of corruption E-ID card is a case that has since 3 (three) years ago investigated by the Commission and has not been resolved until today and had 2 (two ) the person determined to be a suspect and many witnesses who have been examined by the Commission graft procurement project E-KTP. This study aims to determine Domain Discourse, Subject Discourse and Tools Discourse in reporting corruption cases E-KTP in Liputan6.com site. The method used is a qualitative research MAK Halliday social semiotic approach in defining the text of a news and review thesystem in the form of sign language generated by humans. The results of this study indicate that there are three different contexts, namely the Domain Discourse, Subject Discourse and Tools Discourse. In the Domain Discourse that made Nazaruddin words that reveal there is a flow of funds E-ID card project to a certain political parties who sit in the House. The immediate goal is that people or readers know that this case is a big and difficult cases handled by KPK today. Long-term goal is this news or placed on online media sites so that people can read anytime and anywhere. Subject Discourse in this newsthat is quoted were Nazaruddin, Novanto, Febri Diansyah, Sugiharto, Ganjar Pranowo, Markus Nari, Chairuman Harahap, Junaidi, Elza Syarif, Basaria Panjaitan, and Irman. Their role there is a witness, a suspect, spokesman and lawyers. Some social distance among them which has a distance and tone; others have a relationship like Nazaruddin, Novanto, Ganjar Pranowo, Chairuman Harahap, and Markus Nari had worked a member of DPR Commission II. Irman, Sugiharto, and Junaidi both working at the Ministry of Internal Affairs. Febri Diansyah and Basaria Panjaitan was KPK spokesman. Elza syarif was attorney Nazaruddin. Furthermore tools discourse in this news style of language used is Eufisme, Aptronim, Apofasis, Majas Tautology, Contradiction Minus And Ellipsis. What type of interaction is dialogical. The medium used is writing. Channels visual form because this story was written, and only can be seen. Rhetorical mode that is used is persuasive because it aims to influence the attitudes of the public and readers to always follow the news.
\end{abstract}

\section{Keywords: Liputan6.Com, E-KTP Corruption News, MAK Halliday}

\section{PENDAHULUAN \\ Latar Belakang}

Perkembangan media massa saat ini merupakan kebutuhan, dalam mendukung berbagai aktifitas masyarakat. Dalam era global saat ini teknologi yang berkembang, kian memudahkan masyarakat dalam memperoleh informasi secara cepat dan mengikuti perkembangan.Karena media adalah perpanjangan lidah dan tangan yang berjasa meningkatkan kapasitas manusia untuk mengembangkan struktur sosialnya 
(Rivers, 2004: 27). Kebutuhan masyarakat akan informasi yang cepat saat ini, dimanfaatkan oleh berbagai media massa dalam perannya menyampaikan informasi, edukasi, opini, dan ilmu pengetahuan kepada para pembacanya. Dalam mencukupi kebutuhan khalayak, media massa umumnya selalu aktif dalam memproduksi informasi yang cepat, hangat dan orisinil.

Media massa pada dasarnya dapat dibagi menjadi dua kategori yakni media massa cetak dan media massa elektronik (Ardianto 2004:98). Akan tetapi saat ini media massa bukan hanya didominasi oleh media cetak dan elektronik saja, sekarang ada yang namanya media online. Media online adalah media massa yang tersaji secara online di situs web (website) internet (Romli, 2012).Dengan adanya media online ini khalayak dapat dengan mudah mencari informasi mengenai berita yang sedang hangat, karena jangkauan media online sangat luas dan informasi yang disampaikan selalu terbaru dan khalayak juga dapat membaca dimana saja dan kapan saja tanpa memerlukan waktu khusus.Sama seperti media lainnya media online juga memberitakan tentang bencana alam, politik atau korupsi dan lain-lain.Karena berita adalah suatu fakta atau ide atau opini aktual yang menarik dan akurat serta dianggap penting bagi sejumlah besar pembaca, pendengar maupun penonton (Holt-Reinhart \& Winston 1975 hal 44). Hampir semua kalangan masyarakat menyukai berita apa lagi berita tersebut masalah kasus korupsi yang menyangkut pejabat pemerintahan.

Saat ini berita kasus korupsi yang sedang memanas yaitu,berita tentang kasus korupsi E-KTP, dan salah satu media online yang memberitakan kasus korupsiE-KTP adalah situs liputan6.com. Karena situs ini selalu menyajikan berita terbaru dan lebih akurat dalam menyampaikan berita, akan tetapi walaupun situs ini selalu memberikan berita terbaru, pembaca tetap bisa membaca berita yang sudah lama karena situs ini tidak menghapus berita lama sehingga pembaca dapat dengan mudah membacanya kembali. Situs ini juga lebih banyak dilihat dan dikenal oleh masyarakat karena situs ini merupakan cabang dari berita liputan6 yang disiarkan oleh salah satu stasiun televisi swasta yaitu SCTV.

Berita tentang kasus korupsi EKTP sejak 3 tahun yang lalu sudah diberitakan di situs liputan6.com dan kasusini belum terselesaikan hingga sekarang karena masih dilakukan penyelidikan oleh KPK. Menurut berita di situs liputan6.com yaitu "menyisir jejak korupsi E-KTPdari nyanyian Nazaruddin" dalam berita tersebut KPK menyebutkanbahwa banyak pejabat pemerintah maupun beberapa anggota dari DPR yang menjadi saksi, dan sudah ada dua orang yang dijadikan tersangka yaitu mantan Direktur Pengelola Infomasi Administrasi Kependudukan Ditjen Dukcapil Sugiharto dan mantan Dirjen Dukcapil yaitu Irman,dan tidak menutup kemungkinan yang sekarang menjadi saksi akan berganti menjadi tersangka jika sudah terbukti bersalah dalam kasus korupsi E-KTP tersebut. Menurut keterangan KPK dalam berita di situs liputan6.com menyebutkan bahwa kerugian Negara terkait kasus korupsi E-KTP sudah mencapai 2,3 triliun lebih. Penulis menganalisis berita tersebut dikarenakan berita "menyisir jejak 
korupsi E-KTP dari nyanyian Nazaruddin" lebih menjelaskan secara lebih lengkap mengenai kasus korupsi E-KTP tersebut.

Melihat berita tentang kasus korupsi E-KTP yang diberitakan oleh situs liputan6.com tersebut penulisingin mengetahui bagaimana dalam hal ini liputan6.com mewacanakan teks pada berita kasus korupsi E-KTP tersebut. Dengananalisis semiotika sosial dengan menggunakan metode MAK Halliday, karena semiotika ini khusus menelaah sistem tanda yang dihasilkan oleh manusia berupa lambang dan kalimat. Dengan kata lain semiotika menelaah sistem tanda yang terdapat dalam bahasa.

Dari latar belakang diatas, maka permasalahan yang dapat dirumuskan dalam penelitian ini adalahsebagai berikut :

1. Bagaimana medan wacana dalam pemberitaan kasus korupsi E-KTP di situs liputan6.com?

2. Siapa pelibat wacana dalam pemberitaan kasus korupsi EKTP di situs liputan6.com?

3. Bagaimana sarana wacana dalam pemberitaan kasus korupsi EKTPdi situs liputan6.com?

Dalam penelitian ini penulis membatasi masalah yaitu penulis menganalisis, berita tanggal 14 Desember 2016“menyisir jejak korupsi E-KTP dari nyanyian Nazaruddin" di situs Liputan6Com.

\section{Semiotika Sosial MAK Halliday} Semiotika sosial MAK Halliday dalam bukunya yang berjudul language social semiotic.Semiotika sosial merupakan cabang dari studi mengenai tanda yang khusus menelaah sistem tanda yang dihasilkan oleh manusia yang berwujud lambang, baik lambang berwujud kata maupun lambang berwujudd kata dalam satuan yang disebut kalimat. Dengan kata lainsemiotika sosial menelaah sistem tanda yang terdapat dalam bahasa (Sobur 2002: 101).

Selain itu, istilah semiotika sosial merupakan hubungan setiap manusia dengan lingkungan manusia yang memiliki arti, dan arti tersebut akan dimaknai oleh-oleh orang-orang yang saling berinteraksi dengan melibatkan lingkungan tersebut. Menurut Halliday dan Hasan istilah semiotika sosial diartikan secara berbeda yaitu semiotika dan sosial. Konsep "semiotik" mulanya berasal dari konsep tanda, dan kata modern ini ada hubunganny dengan istilah semainon(penanda) dan semainomenon (petanda) yang digunakan dalam ilmu bahasa yunani kuno oleh pakar filsafat stoik (Halliday dan Hasan 1994:3). Sedangkan 'sosial' yang artinya sistem sosial atau kebudayaan sebagai suatu sistem makna (Halliday dan Hasan 1994:3).

Dengan demikian, semiotika sosial itu sendiri merupakan suatu pendekatan yang memberi tekanan pada konteks sosial, yaitu pada fungsi sosial yang menentukan bentuk bahasa.Perhatian utamanya terletak pada hubungan antara bahasa dengan struktur sosial dengan memandang struktur sebagai satu segi dari sistem sosial (Halliday dan Hasan 1994:3). Aliran Halliday juga dikenal pula dengan sebutan semiotik behavioris yang mengambangkan teori semiotik dengan jalan memanfaatkan temuantemuan baru dalam psikologi yang berpengaruh pada linguistik (Rusmana 2014:216).Semiotika sosial lebih menelaah mengenai 
bahasa. Karena bahasa sebagai salah satu makna yang secara bersamasama membentuk budaya manusia (Halliday dan Hasan 1994:5) .Bahasa juga sangat diperlukan dalam kebutuhan manusia untuk memahami seseorang dalam kehidupan.

Bahasa sebagai semiotik sosial yang terjadi dari tiga unsur, yakni arti, bentuk, dan ekspresi.Secara teknis disebut semantik, tata bahasa (lexicogrammar) dan fonologi (lisan), grafologi (tulisan), atau sign(isyarat) (Saragih 2006:227). Jadi, dari unsur pertama yaitu arti direalisasikan oleh bentuk (kosa kata dan tata bahasa) kemudian bentuk mengekspresikannya melalui bunyi yang berupa bahasa lisan dalam tulisan.Hubungan ketiga unsur ini dalam persepsi bahasa sebagai semiotik sosial.

Dalam bahasa berkaitan pula teks dengan konteks. Menurut Dadan Rusmana, teks adalah bahasa yang sedang melaksanakan tugas untuk mengekspresikan fungsi atau makna sosial dalam konteks situasi dan konteks kultural (Rusmana 2014:219). Kemudian Halliday dan Hasan bahwa teks dibatasi sebagai unit bahasa yang fungsional dalam konteks sosial.

Ada teks dan ada teks lain yang menyertainya: teks yang menyertai teks itu disebut konteks. Namun, pengertian mengenai hal yang menyertai teks itu meliputi yang diisikan atau ditulis, tetapi juga meliputi kejadian-kejadian yang nonverbal lainnya pada keseluruhan lingkungan teks itu (Halliday dan Hasan 1994:6). Konteks pun terbagi menjadi tiga yaitu konteks situasi (field, tenor, dan mode), konteks budaya, dan konteks ideologi.

Konteks situasi itu sendiri adalah keseluruhan lingkungan, baik lingkungan tutur (verbal) maupun lingkungan tempat teks itu diproduksi (diucapkan atau ditulis). Ketiga konteks situasi berkaitan dengan tiga metafungsi penggunaan bahasa di dalam proses sosial pada masyarakat. Ketiga metafungsi bahasa, yaitu sebagai berikut : fungsi ideasional, fungsi interpersonal, dan fungsi tekstual.

Dalam pandangan Halliday konteks situasi terdiri atas tiga unsur, yakni, medan wacana, pelibat wacana dan sarana wacana (Santoso 2008:4).

1. Medan wacana (field of discourse) merujuk kepada aktivitas sosial yang sedang terjadi serta latar institusi tempat satuan-satuan bahasa itu muncul. Untuk menganalisis medan wacana (field discourse), kita dapat mengajukan pertanyaan what is going on (apa yang sedang terjadi), yang mencakup tiga hal, yakni ranah pengalaman, tujuan jangkapendek, dan tujuan jangka panjang. Ranah pengalaman merujuk kepada ketransitifan yang mempertanyakan apa yang terjadi dengan seluruh proses, partisipan, dan keadaan. Tujuan jangka pendek merujuk pada tujuan yang harus segera dicapai. Tujuan jangka panjang merujuk pada tempat teks dalam skema suatu persoalan yang lebih besar.

2. Pelibat wacana (tenor of discourse) merujuk pada hakikat relasi antarpartisipan, termasuk pemahaman peran dan statusnya dalam konteks sosial dan lingual. Untuk menganalisis pelibat, kita dapat mengajukan pertanyaan who is taking part atau siapa yang terlibat. Dalam pelibat wacana ada tiga hal yang perl diungkap yaitu : peran, status sosial, dan jarak 
sosial. Peran, status sosial dan jarak sosial dapat bersifat sementara dan dapat pula permanen.

3. Sarana wacana (mode of discourse) merujuk pada bagian bahasa yang sedang dimainkan dalam situasi, termasuk saluran yang dipilih, apakah lisan atau tulisan. Untuk menganalisis sarana paling tidak ada lima hal yang perlu diungkap ; peran bahasa, tipe interaksi, medium, saluran dan modus retoris. Peran bahasa terkait dengan kedudukan bahasa dalam aktivitas bisa saja bersifat wajib (konstitutif) atau tidak wajib. Peran tambahan terjadi apabila bahasa membantu aktivitas lainnya. Tipe interaksi merujuk pada jumlah pelaku: monologis atau dialogis. Medium terkait dengan sarana yang digunakan lisan, tulisan, atau isyarat. Saluran berkaitan dengan bagaimana teks itu dapat diterima yaitu berupa vonis, grafis, dan visual. Modus retoris merujuk pada "perasaan" teks secara keseluruhan.

\section{Korupsi}

Korupsi berasal dari bahasa
latin yaitu corruptio dari kata
kerja corrumpereyang bermakna
(busuk, rusak, menggoyahkan,
memutarbalik, dan menyogok)
korupsi adalah tindakan pejabat
publik, baik politisi maupun pegawai
negeri, serta pihak lain yang terlibat
dalam tindakan itu yang secara tidak
wajar
tidak legal menyalahgunakan
kepercayaan publik yang dikuasakan
kepada mereka untuk mendapatkan
keuntungan
(www.kpk.go.id).

Seseorang bisa dikatakan korupsi jika mereka memberi atau menerima hadiah atau janji (penyuapan), penggelapan dalam jabatan, pemerasan dalam jabatan, ikut serta dalam pengadaan (bagi pegawai negeri/penyelenggara negara),dan menerima gratifikasi ( bagi pegawai negeri/penyelenggara negara) www.kpk.go.id.

Menurut UU NO.31/1999 jo UU No.20/2001 menyebutkan bahwa pengertian korupsi mencakup perbuatan:

- Melawan hukum, memperkaya diri orang/badan lain yang merugikan keuangan /perekonomian negara (pasal 2).

- Menyalahgunakan kewenangan karena jabatan/kedudukan yang dapat merugikan keuangan/kedudukan yang dapat merugikankeuangan/perekonomia n negara (pasal 3)

- Kelompok delik penyuapan (pasal 5,6, dan 11)

- Kelompok delik penggelapan dalam jabatan (pasal 8, 9, dan 10)

- Delik pemerasan dalam jabatan (pasal 12)

- Delik yang berkaitan dengan pemborongan (pasal 7)

- Delik gratifikasi (pasal 12B dan 12C)

\section{E-KTP}

E-KTP atau KTP Elektronik adalah dokumen kependudukan yang memuat sistem keamanan / pengendalian baik dari sisi administrasi ataupun teknologi informasi dengan berbasis pada database kependudukan nasional. Penduduk hanya diperbolehkan memiliki 1 (satu) KTP yang tercantum Nomor Induk Kependudukan (NIK). NIK merupakan identitas tunggal setiap 
penduduk dan berlaku seumur hidup.(www.e-ktp.com). Adapun Fungsi dan Kegunaan E-KTP adalah

1. Sebagai identitas jati diri

2. Berlaku Nasional, sehingga tidak perlu lagi membuat KTP lokal untuk pengurusan izin, pembukaan rekening Bank, dan sebagainya

3. Mencegah KTP ganda dan pemalsuan KTP; Terciptanya keakuratan data penduduk untuk mendukung program pembangunan.

Penerapan KTP berbasis NIK (Nomor Induk Kependudukan) telah sesuai dengan pasal 6 Perpres No.26 Tahun 2009 tentang Penerapan KTP berbasis Nomor Induk Kependudukan Secara Nasional Jo Perpres No. 35 Tahun 2010 tentang perubahan atas Perpres No. 26 Tahun 2009 yang berbunyi :

1. KTP berbasis NIK memuat kode keamanan dan rekaman elektronik sebagai alat verifikasi dan validasi data jati diri penduduk;

2. Rekaman elektronik sebagaimana dimaksud pada ayat (1) berisi biodata, tanda tangan, pas foto, dan sidik jari tangan penduduk yang bersangkutan;

3. Rekaman seluruh sidik jari tangan penduduk disimpan dalam database kependudukan;

4. Pengambilan seluruh sidik jari tangan penduduk sebagaimana dimaksud pada ayat (3) dilakukan pada saat pengajuan permohonan KTP berbasis NIK, dengan ketentuan : Untuk WNI, dilakukan di Kecamatan; dan Untuk orang asing yang memiliki izin tinggal tetap dilakukan di Instansi Pelaksana.

5. Rekaman sidik jari tangan penduduk yang dimuat dalam
KTP berbasis NIK sebagaimana dimaksud pada ayat (2) berisi sidik jari telunjuk tangan kiri dan jari telunjuk tangan kanan penduduk yang bersangkutan;

6. Rekaman seluruh sidik jari tangan penduduk sebagaimana dimaksud pada ayat (3) dapat diakses oleh pihak-pihak yang berkepentingan sesuai dengan peraturan perundang-undangan;

7. Ketentuan lebih lanjut mengenai tata cara perekaman sidik jari diatur oleh Peraturan Menteri. (www.e-ktp.com)

\section{Berita}

Berita adalah laporan tentang fakta atau ide yang termassa, yang dapat menarik perhatian pembaca, karena sesuatu yang luar biasa, penting, mencakup sisi human interest seperti humor, emosi dan ketegangan (Menurut Assegaf, dalam Sumadiria 2005: 64-65).

Sedangkan Mitchel V. Charnley dalam bukunya Reporting edisi III (Holt-Reinhart \& Winston, New York, 1975 halaman 44) menyebutkan berita adalah laporan yang tepat waktu mengenai fakta atau opini yang memiliki daya tarik atau hal penting atau kedua-duanya bagi masyarakat luas.

Dalam Buku "Dasar-Dasar Jurnalistik" A.M. Hoeta Soehoet. Beliau adalah pendiri sekaligus Mantan Rektor Institut Ilmu Sosial dan Ilmu Politik (IISIP) Jakarta:
1) Berita adalah keterangan mengenai peristiwa atau isi pernyataan manusia
2) Berita bagi seseorang adalah peristiwa atau isi pernyataan seseorang yang menurutnya perlu diketahui untuk mewujudkan filsafat hidupnya 
3) Berita bagi suatu suratkabar adalah keterangan mengenai peristiwa atau isi pernyataan yang perlu bagi pembacanya untuk mewujudkan filsafat hidupnya

Suatu peristiwa bisa disebut berita apabila sudah disiarkan, dilaporkan, atau diinformasikan. Berita dalam media cetak dapat dilihat pada surat kabar, tabloid, atau majalah.

Dengan demikian dapat disimpulkan bahwa berita adalah suatu fakta atau ide atau opini aktual yang menarik dan akurat serta dianggap penting bagi sejumlah besar pembaca, pendengar maupun penonton.

\section{Media Online}

Media online adalah sebutan umum untuk sebuah bentuk media yang berbasis telekomunikasi dan multimedia (baca-komputer dan internet). Didalamnya terdapat portal, website (situs web), radioonline, TV-online, pers online, mailonline, dll, dengan karakteristik masing-masing sesuai dengan fasilitas yang memungkinkan user memanfaatkannya (Ashadi Siregar dalam Kurniawan, 2005: 20).

Kelebihan media online yang memikat para penikmat media ini yaitu informasi bersifat up to date (senantiasa baru), informasi bersifat real time, dan informasinya bersifat praktis (suryawati 2011:6). Dengan demikian media online yang memiliki banyak kelebihan ini sangat diminati masyarakat.Bahkan media online sangat unggul dibanding media lainnya.dikarena masyarakat juga mudah setiap waktu untuk mengakses internet.keunggukan layanan online ini juga yang kemudian juga memicu media massa membentuk situs online. jurnalistik melalui media media internet pun semakin berkembang bahkan sejumlah media massa yang awalnya merintis sebagai media cetak ataupun elektronik melahirkan portal berita dalam bentuk media online.

Menurut Zaenuddin dalam bukunya the journalist (2011:7-8) Media online memiliki kelebihan dibandingkan dengan media cetak yaitu :

1) Berita-berita yang disampaikan jauh lebih cepat, bahkan setiap beberapa menit dapat di update.

2) Untuk mengakses berita-berita yang diasajikan, tidak hanya dapat dilakukan lewat computer atau laptop yang dipasang jaringan internet, tetapi melalui ponsel atau HP pun bisa sangat mudah dan praktis.

3) Pembaca media online dapat memberikan tanggapan atau komentar secara langsung terhadap berita-berita yang disukai atau yang tidak disukai dengan menarik kolom komentar yang telah disediakan.

\section{Situs Atau WebsiteLiputan6.Com \\ Liputan6.com merupakan}

situsatauWebsite yang menyajikan beraneka ragam informasi pilihan bagi para penggunanya.Situs ini didirikan oleh PT Kreatif Media Karya pada 24 Agustus 2000 dan mulai di resmikan tahun 2001yang juga merupakan anak perusahaan Elang Mahkota Teknologi dan cabang dari berita liputan 6 yang ada di SCTV.

Liputan6.com menyajikan berbagai topik menarik, dimulai dari informasi politik, bisnis, gaya hidup, kuliner, hingga berita olahraga. Liputan6.com bukan hanya menyajikan berita terbaru, tetapi juga 
memilihkan berita yang tepat untuk masyarakat.

Website merupakan kumpulan halaman web yang saling terhubung dan file - filenya saling terkait. Web terdiri dari page atau halaman, dan kumpulan halaman yang dinamakan homepage.Homepage berada pada posisi teratas, dengan halaman halaman terkait berada di bawahnya. Biasanya setiap halaman di bawah homepage disebut child page, yang berisi hyperlink ke halaman lain dalam web. (Gregorius, 2000, h:30).

Website awalnya merupakan suatu layanan sajian informasi yang menggunakan konsep hyperlink, yang memudahkan surfer atau pengguna internet melakukan penelusuran informasi di internet.Informasi yang disajikan dengan web menggunakan konsep multimedia, informasi dapat disajikan dengan menggunakan banyak media, seperti teks, gambar, animasi, suara, atau film.

Website merupakan fasilitas internetyang menghubungkan dokumen dalam lingkup lokal maupun jarak jauh. Dokumen pada website disebut dengan web page dan link dalam website memungkinkan pengguna bisa berpindah dari satu page ke page lain (hyper text), baik diantara page yang disimpan dalam server yang sama maupun server diseluruh dunia. Pages diakses dan dibaca melalui browser seperti Netscape Navigator atau Internet Explolerdan berbagai aplikasi browser lainnya. (Hakim Lukmanul. 2004 : Cara Cerdas Menguasai Layout, Desain, dan Aplikasi).

\section{METODE PENELITIAN}

Dalam setiap penelitian pasti menggunakan metode untuk menganalisa dan mendeskripsikan suatu masalah, sehingga suatu masalah dapat diuraikan dan dijelaskan dengan baik serta dapat dipahami.Dalam penelitian ini jenis penelitian yang digunakan oleh penulis adalah penelitian kualitatif.Dengan subjek penelitian situs liputan6.com dan objek penelitiannya berita tentang kasus korupsi E-KTP. Dengan menggunakan metode analisis semiotika sosial MAK Halliday untuk mengetahui Medan Wacana,Pelibat Wacana dan Sarana Wacana.

Menurut Bogdan dan Taylor (1975) yang dikutip oleh Moleong (2007:4) mengemukakan bahwa metedologi kualitatif sebagai prosedur penelitian yang menghasilkan data deskriptif berupa kata-kata tertulis atau lisan dari orang-orang dan perilaku yang diamati.

Selanjutnya dijelaskan oleh David Williams (1995) seperti yang dikutip Moleong (2007:5) mengemukakan bahwa penelitian kualitatif adalah pengumpulan data pada suatu latar alamiah, dengan menggunakan metode alamiah, dan dilakukan oleh orang atau peneliti yang tertarik secara alamiah.

Penelitian ini menggunakan metedologi kualitatif dengan analisis semiotika sosial yaitu metode MAK Halliday untuk menganalisis isi dan teks media berita di liputan6.com, berhubungan dengan berita kasus korupsi E-KTP.

Teknik pengumpulan data yang digunakan oleh penulis yaitu :

1. Dokumentasi

Dokumentasi adalah teknik mengumpulkan data-data dengan cara mengkaji bukubuku, website dan literature 
lainnya yang berhubungan dengan materi penelitian. Dalam penelitian ini penulis mengumpulkan data dengan mencari buku-buku yang terkait semiotika sosial di perspustakaan. Dan mengumpulkan data berupa berita kasus korupsi E-KTP di situs liputan6.com dengan cara mengeprint screen setiap bagian dari berita tersebut.

2. Studi pustaka

Studi pustaka adalah mempelajari berbagai buku sebagai referensi serta hasil penelitian sebelumnya yang sejenis yang berguna untuk mendapatkan landasan teori mengenai masalah yang akan diteliti (Sarwono 2006). Dalam penelitian ini penulis menjadikan beberapa jurnal dan skripsi yang menggunakan metode yang sama dengan penulis untuk menjadi bahan referensi, untuk memudahkan penulis dalam membuat penelitian, dengan cara mendownload skripsi tersebut.

Dalam penelitian ini analisis data yang digunakan oleh penulis adalah analisis semiotika sosial MAK Halliday, yaitu :

1. Medan Wacana (field ofdiscourse) Tujuannya untuk mengetahui apa yang dijadikan wacana media massa mengenai sesuatu yang terjadi di lapangan atau peristiwa, serta untuk mengetahui tiga hal berikut, ranah pengalaman, tujuan jangka pendek, dan tujuan jangka panjang.Ranah pengalaman maksudnya untuk mengetahui bagaimana keadaan yang digambarkan oleh liputan6.com tentang berita kasus korupsi E-
KTPtersebut. Tujuan jangka pendek yaitu untuk mengetahui apa tujuan yang ingin dicapai oleh liputan6.com terkait berita tersebut. Sedangkan tujuan jangka panjangnya yaitu untuk mengetahui tempatteks berita tersebut.

2. Pelibat Wacana (tenor of discourse)

Untuk megetahui orang-orang yang

dicantumkan dalam teks (seperti berita, editorial, dan lain-lain); dan untuk mengetahui peran, status sosial, dan jarak sosial dari orang-orang yang dikutip dalam berita kasus korupsi EKTP oleh situs liputan6.com tersebut.

3. Sarana Wacana (mode of discourse)

Tujuannya untuk mengetahui bagian yang diperankan oleh bahasa: bagaimana komunikator (media massa) menggunakan gaya bahasa untuk menggambarkan medan (situasi) dan pelibat (orang-orang yang dikutip). Dan untuk mengetahui peran bahasa yaitu bagaimana penggunaan gaya bahasa dalam berita tersebut. Tipe interaksi yaitu untuk merujuk pada jumlah pelaku yang ada dalam berita tersebut.Medium yaitu untuk mengetahui sarana yang digunakan oleh lipuan6.com apakah tulisan,lisan atau isyarat.Saluran yaitu bagaimana teksberitakasus korupsi EKTPdapat diterima yaitu, vonis, grafis, dan visual. Dan modus retoris yaitu merujuk pada teks secara keseluruhan dalam berita kasus liputan6.com tersebut. 
HASIL PENELITIAN DAN PEMBAHASAN

Hasil Penelitian

Analisis Semiotika Sosial MAK

Halliday Pada Berita Kasus

Korupsi E-Ktp di Situs

Liputan6.Com

Pada bab ini peneliti akan menganalisis berita kasus korupsi tanggal 14 Desember 2016 "Menyisir Jejak Korupsi E-KTP Dari Nyanyian Nazaruddin" di situs liputan6.com dengan menggunakan metode MAK Halliday, yaitu Medan Wacana, Pelibat Wacana, dan Sarana Wacana.

Dalam berita kasus korupsiEKTP diliputan6.com tersebut, dilihat dari medan wacana yaitu yang dijadikan wacana oleh liputan6.com adalah KPK yang menyelidiki perkataan Nazaruddin, yang mengatakan bahwa adanya aliran dana kepada sejumlah partai politik tertentu yang masih duduk di DPR terkait kasus korupsi E-KTP. Pernyataan ini ditegaskan oleh kutipan pada berita tanggal 14 Desember 2016 :

Liputan6.com, Jakarta -
Komisi Pemberantasan
Korupsi ( $\underline{\text { KPK }})$ pernah
menyebut dugaan korupsi
proyek E-KTP pada 2011-
2012, sebagai kasus yang agak
pelik penanganannya.Komisi
antirasuah itu pun menyisir
kasus tersebut, salah satunya
melalui omongan terpidana
kasus korupsi Muhammad
Nazaruddin.

Yang dijadikan wacana selanjutnya adalah KPK juga telah memeriksa saksi salah satunya ketua DPR Setya Novanto dan Gubenur jawa tengah Ganjar pranowo sebagai saksi untuk tersangka Sugiharto. Pernyataan ini ditegaskan oleh kutipan pada berita tanggal 14 Desember 2016 :

Liputan6.com, Jakarta-KPK, Selasa 13 Desember 2016, memeriksa Ketua DPR Setya Novanto. KPK mengklarifikasi sejumlah hal terkait proyek EKTP yang menelan anggaran negara $R p \quad 5,9$ triliun itu kepada pria yang akrab disapa Setnov tersebut. Sebelumnya, KPK telah memeriksa Gubernur Jawa Tengah Ganjar

Pranowo.Ganjar juga diperiksa sebagai saksi terkait kasus dugaan korupsi proyek pengadaan E-KTP tahun 20112012 untuk tersangka Sugiharto.

Dan yang dijadikan wacana terakhiroleh liputan6.comyaitu, penanganan kasus E-KTP yang merupakan salah satu kasus besar yang tengah ditangani KPK dan merupakan kasus yang pelik. Pernyataan ini ditegaskan oleh kutipan pada berita tanggal 14 Desember 2016 :

Liputan6.com,Jakarta -Komisi Pemberantasan Korupsi (KPK) menyebut dugaan korupsi proyek E-KTP pada 2011-2012 sebagai salah satu kasus besar yang tengah ditanganinya.Dia juga tak membantah kasus EKTP ini rumit.Selain karena sudah lama, sejumlah saksi sudah purna tugas. "Agak pelik memang ini kasus.Disamping sudah lama, orang-orangnya sudah pensiun," kata Basaria. 
Pengambilan kutipan ini bertujuan untuk memperkuat analisis dari peneliti. Dalam analisis medan wacana ini ada tiga hal yang perlu diketahui, yaitu :

a. Ranah Pengalaman

Maksudnya untuk mempertanyakan apa yang terjadi dengan seluruh proses, partisipan, dan keadaan. Yang terjadi dengan proses pembuatan berita tanggal 14 Desember 2016 "Menyisir Jejak Korupsi E-KTP Dari Nyanyian Nazaruddin" di situs liputan6.com ini atau yang melatarbelakangi wartawan atau situs liputan6.com memberitakan kasus ini adalah dikarenakan beberapa tahun lalu mantan anggota komisi II DPR yaitu Nazaruddin mengungkapkan bahwa ada aliran dana pengadaan E-KTP kepada sejumlah elite partai politik tertentu yang masih duduk di DPR, dan belakangan ini kasus korupsi E-KTP semakin memanas karena kasus ini merupakan kasus yang besar yang tengah ditangani KPK dan belum terselesaikan hingga sekarang. Kasus ini juga banyak melibatkan angota DPR maupun mantan anggota DPR, dan termasuk juga Kemendagri. Melihat kasus E-KTP yang terus berjalan menyebabkan situs liputan6.com memberitakan kasus ini

Selanjutnya apa yang terjadi dengan partisipan maksudnya adalah apa yang terjadi dengan orang-orang yang berperan dalam berita tersebut. Yang terjadi dengan orang tersebut adalah yang pertama Nazaruddin,dia menjadi saksi terkait kasus tersebut dan masih dimintai keterangan oleh KPK untuk mengungkap siapa saja yang terlibat dalam kasus tersebut.Kedua Setya Novanto dan Ganjar Pranowo mereka diperiksamenjadi saksi yang dimintai keterangan oleh KPK untuk tersangkaSugiharto. Selanjutnya Markus Nari, Chairuman Harahap dan Junaidi juga menjadi saksi untuk tersangka Sugiharto. Sedangkan Sugiharto dan Irman menjadi tersangka dalam kasus korupsi E-KTP.Elza Syarif yang menjadi pengacara dari Nazaruddin yang menyebutkan inisial dari orangorang yang diduga ikut terlibat dalam kasus korupsi E-KTP tersebut.Terakhir yaitu Febri Diansyah dan Basaria Panjaitan yang terjadi dengan mereka adalah dalam berita tersebut mereka menjadi narasumber dari KPK yang dimintai keterangan oleh wartawan untuk kasus ini.

Terakhir apa yang terjadi dengan keadaan. Maksudnya apa yang terjadi dengan situasi yang digambarkan oleh wartawan tersebut, situasi yang digambarkan oleh wartawan dapat dilihat dari beberapa kalimat. Cotohnya pada kutipan berikut :

Liputan6.com, Jakarta -
Komisi Pemberantasan
Korupsi (KPK) pernah
menyebut dugaan korupsi
proyek E-KTP pada 2011-
2012, sebagai kasus yang agak
pelik penanganannya. Komisi
Pemberantasan Korupsi (KPK)
menyebut dugaan korupsi
proyek E-KTP pada 2011-2012
sebagai salah satu kasus besar


yang tengah ditanganinya. Dia juga tak membantah kasus EKTP ini rumit.Selain karena sudah lama, sejumlah saksi sudah purna tugas. "Agak pelik memang ini kasus.Disamping sudah lama, orang-orangnya sudah pensiun, "kata Basaria.

Dari beberapa kalimat diatas ditemukan kata-kata seperti, pelik penanganannya, kasus besar, dan rumit dari kata tersebut keadaan yang ingin digambarkan oleh wartawan adalah agar pembaca dapat merasakan bahwa kasus korupsi E-KTP merupakan kasus yang besar yang sedang ditangani KPK dan penyelesaiannya sangatlah sulit.

b. Tujuan Jangka Pendek

Maksudnya apa tujuan yang harus segera dicapai oleh liputan6.com terkait berita tersebut.Tujuan yang harus segera dicapai oleh liputan6.com dilihat dari penulisan berita kasus E-KTP pada tanggal 14 Desember 2016 yaitu, "Menyisir Jejak Korupsi E-KTP Dari Nyanyian Nazaruddin". Dalam penulisannya liputan6.com menuliskan :

Liputan6.com, Jakarta Komisi Pemberantasan Korupsi (KPK) pernah menyebut dugaan korupsi proyek E-KTP pada 20112012, sebagai kasus yang agak pelik penanganannya.Komisi antirasuah itu pun menyisir kasus tersebut, salah satunya melalui omongan terpidana kasus korupsi Muhammad Nazaruddin.

Liputan6.com,Jakarta

Nazaruddin mengungkap ada aliran dana pengadaan Elektronik KTP (E-KTP) kepada sejumlah elite partai politik tertentu yang masih duduk di DPR. Dia mengungkapnya sejak 2013 lalu.

Dilihat dari penulisan diatas bahwa tujuan dari liputan6.com adalah agar orang yang membaca berita ini bisa memahami dengan jelas bahwa kasus ini bermula dari ungkapan Nazaruddin yang menyebutkan bahwa ada aliran dana pengadaan Elektronik KTP (E-KTP) kepada sejumlah elite partai politik tertentu yang masih duduk di DPR. Dia mengungkapnya sejak 2013 lalu, dari salah satu ungkapan tersebut KPK menyelidiki kasus korupsi E-KTP ini. Tujuan lainnya bisa dilihat pada kutipan narasumberBasaria Panjaitan, yaitu:

Liputan6.com,Jakarta -Dia mengatakan, penyidik harus bekerja keras dalam mengusut tuntas kasus ini. Sebab, dia menggarisbawahi, kasus ini tak cuma melibatkan dua tersangka yakni eks Direktur Jenderal Kependudukan dan Pencatatan Sipil (Dukcapil) Kemendagri, Irman, dan pejabat pembuat komitmen (PPK) proyek e-KTP, Sugiharto. 
Dari kutipan diatas bisa dilihat bahwa tujuan dari narasumber adalah agar pembaca atau masyarakat dapat mengetahui bahwa kasus korupsi E-KTP ini merupakan kasus yang pelik atau rumit untuk ditangani.Dari kutipan narasumber juga dapat dilihat bahwa tujuannya untuk penyidik agar dapat bekerja keras dalam menyelesaikan tugas ini.

c. Tujuan Jangka Panjang

Maksudnya adalah tempat teks yang digunakan, teks berita kasus korupsiE-KTP di beritakan oleh media online yaitu situsliputan6.com tujuan jangka panjangnya adalah agar masyarakat bisa terus menerus melihat berita tersebut kapan saja, karena di media online walaupun berita tersebut sudah lama tetapi akan tetap ada disitus tersebut. Bukan hanya itu saja tetapi liputan6.com juga bertujuan mengikuti berita ini dari awal hingga akhirnya kasus ini selesai, dengan selalu memerbaharui beritanya agar masyarakat dapat selalu tahu bagaimana kasus ini berlangsung serta dapat mengetahui siapa yang akan dijadikan tersangka berikutnya oleh KPK.

Dalam berita kasus korupsi EKTP tanggal 14 Desember 2016 "Menyisir Jejak Korupsi E-KTP Dari Nyanyian Nazaruddin" yang terlibat atau yang dikutip oleh liputan6.com tentang berita tersebut adalah Muhammad Nazaruddin, Setya Novanto, Febri Diansyah, Sugiharto, Ganjar Pranowo, Markus Nari, Chairuman Harahap, Junaidi, Elza
Syarif, Basaria Panjaitan, dan Irman. untuk menganalisis pelibat wacana perlu diketahui tiga hal berikut, yaitu :Peran, status sosial dan jarak sosial.

a. Muhammad Nazaruddin, dalam berita ini perannya sebagai saksi yang mengetahui bahwa ada aliran dana proyek E-KTP kepada sejumlah elite partai tertentu yang masih duduk di DPR dan orang yang mengungkap ada aliran dana kepada orang-orang yang terlibat dalam kasus E-KTP tersebut. Pernyataan ini ditegaskan oleh kutipan pada berita tanggal 14 Desember 2016 :

\section{Liputan6.com,Jakarta \\ Nazaruddin mengungkap ada aliran dana pengadaan \\ Elektronik KTP (E-KTP) \\ kepada sejumlah elite partai politik tertentu yang masih duduk di DPR. Dia mengungkapnya sejak 2013 lalu. \\ Terpidana korupsi yang juga mantan anggota DPR $M$ Nazaruddin seusai menjalani pemeriksaan di gedung KPK, Jakarta, Kamis (29/9) Nazaruddin kembali dipanggil KPK terkait kasus pengadaan $e-K T P$.}

Dalam berita ini status sosial dari Nazaruddin tidak di sebutkan tetapi sebenarnya status sosialnya adalah mantan anggota komisi II DPR 2009-2014 yang juga menjadi tersangka kasus suap pembangunan wisma atlet (Hambalang) untuk SEA Games ke-26, juga didakwa mengenai gratifikasi dan pencucian uang melalui berbagai perusahaan miliknya dan sekarang menjadi saksi dalam kasus korupsi E-KTP 
yang diduga menerima aliran dana poyek E-KTP.

b. Setya Novanto, dalam berita kasus E-KTP ini berperan sebagai saksi untuk tersangka Sugiharto.Pernyataan ini ditegaskan oleh kutipan pada berita tanggal 14 Desember 2016 :

Liputan6.com, Jakarta -KPK, Selasa 13 Desember 2016, memeriksa Ketua DPR Setya NovantoKPK mengklarifikasi sejumlah hal terkait proyek $E$ KTP yang menelan anggaran negara $R p$ 5,9 triliun itu kepada pria yang akrab disapa Setnov tersebut. Politikus Golkar itu diperiksa sebagai saksi untuk tersangka Sugiharto.

Dalam berita ini status sosial dari Setya Novanto tidak dijelaskan secara lebih mendalam namun status sosialnya dahulu merupakan anggota komisi II DPR dan saat ini menjabat sebagai ketua DPR dan ketua umum Partai Golongan Karya (Golkar).Setya Novanto diperiksa oleh KPK karena namanya termasuk salah satu yang disebut oleh Nazaruddin menerima aliran dana proyek E-KTP 2011-2012.

c. Febri Diansyah, dalam berita ini berperan sebagai narasumber yang menjelaskan bahwa KPK (penyidik) akan mengklarifikasi sejumlah informasi untuk memperdalam penyidikan kasus tersebut. Pernyataan ini ditegaskan oleh kutipan pada berita tanggal 14 Desember 2016 :

Liputan6.com, Jakarta - "Penyidik akan mengklarifikasi sejumlah informasi untuk memperdalam penyidikan kasus tersebut," kata Juru Bicara KPK Febri Diansyah, saat dikonfirmasi, Jakarta, Jumat 9 Desember 2016.

Status sosialnya saat ini adalah bekerja dikantor KPK sebagai juru bicara dari KPK.

d. Sugiharto dan Irman, dalam berita ini perannya sebagai tersangka dalam kasus korupsi E-KTP. Pernyataan ini ditegaskan oleh kutipan pada berita tanggal 14 Desember 2016 :

Liputan6.com, Jakarta - kasus ini tak cuma melibatkan dua tersangka yakni eks Direktur Jenderal Kependudukan dan Pencatatan Sipil (Dukcapil) Kemendagri, Irman, dan pejabat pembuat komitmen (PPK) proyek e-KTP, Sugiharto.

Tetapi dalam berita tanggal 14 Desember 2016 "Menyisir Kasus Korupsi E-KTP Dari Nyanyian Nazaruddin" tidak di jelaskan apa yang membuat Sugiharto dan Irman ditetapkan menjadi tersangka. Dalam pemberitaan media lainnya dijelaskan bahwa Sugiharto dan Irman dijadikan terasangka karena mereka diduga melakukan penyalahgunaan wewenang untuk memperkaya diri sendiri atau orang lain, yakni dengan menggelembungkan anggaran proyek pengadaan KTP Elektronik.

Status sosialnya adalah, Irmanmerupakanmantan

Direktur Jenderal

Kependudukan dan Pencatatan Sipil (Dukcapil) Kemendagri, dan Sugiharto adalahPejabat 
Pembuat Komitmen (PPK) Direktur Pengelola Informasi Administrasi Kependudukan Ditjen Dukcapail Kemendagri.

e. Ganjar Pranowo, dalam berita kasus E-KTP ini berperan sebagai saksi untuk tersangka Sugiharto. Pernyataan ini ditegaskan oleh kutipan pada berita tanggal 14 Desember 2016 :

Liputan6.com, Jakarta Sebelumnya, KPK telah memeriksa Gubernur Jawa Tengah Ganjar

Pranowo.Ganjar juga diperiksa sebagai saksi terkait kasus dugaan korupsi proyek pengadaan E-KTP tahun 2011 2012 untuk tersangka Sugiharto.

Status sosialnya adalah mantan wakil ketua komisi II DPR dan saat ini sebagai orang nomor satu dijawa tengah yaituGubernur Jawa Tengah. Ganjar diperiksa oleh KPK sebagai saksi karena sama seperti Setya Novanto, nama Ganjar Pranowo juga disebut oleh Nazaruddin menerima aliran dana proyek E-KTP, dalam salah satu media online Ganjar menyebutkan bahwa dirinya tidak terlibat dan dia siap membantu KPK untuk mengungkapkan sebenarnya siapa saja yang terlibat dalam kasus korupsi E-KTP.

f. Markus Nari, Chairuman Harahap, dan Junaidi, mereka bertiga dalam berita kasus ini berperan sebagai saksi kasus korupsi E-KTP. Pernyataan ini ditegaskan oleh kutipan pada berita tanggal 14 Desember 2016 :

Liputan6.com, Jakarta -Tak hanya dua nama tenar itu, KPK pun telah memeriksa anggota DPR Markus Nari dan mantan Ketua Komisi II DPR Chairuman Harahap, serta seorang PNS Kementerian Dalam Negeri, Junaidi.

Dalam berita ini status sosial dari ketiga saksi tersebut juga tidak dijelaskan secara mendalam tetapi sebenarnya, Markus Narimerupakan anggota komisi II DPR dan juga merupakan politikus dari partai GOLKAR. Selanjutnya Chairuman Harahap yaitu mantan Ketua Komisi II DPR, dan Junaidi yaitu PNS Kementerian Dalam Negeri.Dalam pemberitaan lainnya diberitakan bahwa Markus Nari diperiksa untuk melengkapi berkas penyidikan tersangka Sugiharto, sedangkan Chairuman Harahap diperiksa untuk melengkapi berkas penyidikan tersangka Irman.

g. Elza Syarif, dalam berita kasus ini berperan sebagai narasumber dan pengacara dari Nazaruddin yang dimintai keterangan oleh liputan6.com, serta yang mengungkap inisial dari orang-orang diduga terlibat dalam kasus korupsi EKTP. Pernyataan ini ditegaskan oleh kutipan pada berita tanggal 14 Desember 2016 : 
Liputan6.com, Jakarta Pengacara Elza Syarif mengatakan, sejumlah elite itu diduga terlibat korupsi dalam proyek E-KTP senilai $R p$ 5,9 triliun. Disinyalir telah terjadi penggelembungan harga hingga 45 persen.

Namun, dia enggan mengungkapkan siapa saja anggota dewan yang terlibat dalam mega proyek tersebut.Dia berdalih baru dapat menyebutkan inisialnya saja, lantaran kasus ini tengah diproses KPK.

"Inisialnya itu ada $S N$ dan AU.Lalu dari DPR itu ada MM, Olly DK, MA.Sementara dari pelaksananya AN, terus AS termasuk Nazaruddin juga terlibat.Terus ada GA, EG.Sudah itu dulu.Nanti lagi," singkat Elza di Gedung KPK, usai mendampingi pemeriksaan Nazarudin di Gedung KPK, Jakarta, Selasa 27 Agustus 2013.

Elza pun mengaku ada buktibukti di kertas lainnya.Dokumen itu pun sudah diserahkan kepada penyidik KPK untuk diproses."Ada semua buktibukti sudah rapi.Tapi kasusnya masih dalam penyelidikan," pungkas Elza.

Status sosialnya adalah seorang pengacara yang saat ini menjadi pengacara dari Nazaruddin terkait beberapa kasus yaitu kasus Hambalang, gratifikasi dan pencucian uang dan sekarang kasus korupsi EKTP. h. Basaria Panjaitan, berperan sebagai narasumber dari KPK yang menjelaskan bahwa kasus korupsi E-KTP sebagai salah satu kasus besar yang tengah ditangani. Pernyataan ini ditegaskan oleh kutipan pada berita tanggal 14 Desember 2016 :

Liputan6.com, Jakarta Komisi Pemberantasan Korupsi (KPK) menyebut dugaan korupsi proyek EKTP pada 2011-2012 sebagai salah satu kasus besar yang tengah ditanganinya.Sudah ada dua tersangka dalam kasus tersebut.Untuk menelusuri kembali kasus ini, KPK juga telah memeriksa sejumlah saksi.

"Sampai sekarang sudah 110 yang kita panggil," kata Wakil Ketua KPK, Basaria Panjaitan, di Jakarta, Rabu 16 November 2016.

Status sosialnya saat ini menjabat sebagai wakil ketua KPK.

Dalam berita ini sebenarnya tidak dijelaskan apa jarak sosial antara pelibat, tetapi disini peneliti akan menjelaskan apa jarak sosial antara pelibat tersebut adalah, Nazaruddin, Markus Nari, Chairuman Harahap, Ganjar Pranowo dan Setya Novanto dahulu merupakan anggota komisi II DPR 2009-2014. Pada saat mereka masih duduk dikomisi II DPR mereka diduga menerima aliran dana proyek E-KTP tahun 2011-2012, walaupun sekarang Markus Nari dan Setya 
Novanto masih anggota DPR. Bukan hanya hubungan saat menjadi anggota komisi II DPR saja namun antara Ganjar Pranowo dan Nazaruddin juga mempunyai jarak karena mereka berasal dari partai yang berbeda Ganjar Pranowo adalah fraksi partai PDIP sedangkan Nazaruddin berasal dari fraksi partai Demokrat.Dimana kedua partai politik tersebut sangat mempunyai jarak karena ada permasalahan antara ketua umum dari kedua partai. Jarak antara Setya Novanto dan Nazaruddin juga sama karena berasal dari partai politik yang berbeda Setya Novanto berasal dari fraksi partai Golkar.

SelanjutnyaFebri Diansyah dan Basaria Panjaitan merupakan samasamapenyidik KPK yang juga menyelidiki kasus korupsi EKTP.Sedangkan Elza Syarif dan Nazaruddin jarak sosialnya yaitu Elza Syarif sebagai pengacara dari Nazaruddin.Elza menjadi pengacara Nazaruddin mulai dari kasus Hambalang hingga sekarang kasus korupsi E-KTP. SedangkanIrman dan Sugiharto hubungannya adalah mereka merupakan mantan Ditjen Dukcapil Kemendagri dimana pada saat itu Irman merupakan bekas atasan langsung Sugiharto di Kemendagri dan mereka juga samasama terlibat dalam pembuatan proyek E-KTP.

Dalam Sarana Wacana pada berita kasus korupsi E-KTP tanggal 14 Desember 2016 disitusliputan6.com ada lima hal yang perlu diuangkap yaitu :
a. Peran Bahasa
Peran bahasa atau gaya bahasa yang digunakan dalam berita kasus korupsi E-KTP tanggal 14 Desember 2016 disitus liputan6.com yaitu :

1.) Majas Eufisme adalah majas dengan cara menggantikan kata-kata yang dipandang kurang pantas atau kasar dengan kata-kata yang dianggap lebih pantas atau halus. Contohnya pada kutipan berikut :

Komisi Pemberantasan Korupsi $(\underline{K P K})$ pernah menyebut dugaan korupsi proyek E-KTP pada 20112012, sebagai kasus yang agak pelik penanganannya

Kata pelik dalam kutipan tersebut memiliki gaya bahasa berupa Eufisme karena penggunaan kata pelik dianggap lebih pantas atau halus di bandingkan dengan kata,jarang ada, aneh atau tidak biasa. Akan tetapi lebih baik lagi jika kata pelik tersebut diganti dengan bahasa yang mudah dipahami seperti kata susah. Karena tidak semua orang tahu apa itu pelik.

2.) Majas Aptronimadalah majas dengan cara melekatkan nama khas pada seseorang berdasarkan pekerjaannya. Contohnya pada kutipan berikut :

Politikus Golkar itu diperiksa sebagai saksi untuk tersangka Sugiharto.

Majas Aptronimterdapat dalam kalimatPolitikus Golkar itu.Kata Politikus Golkar itu menunjuk kepada Setya Novanto yang saat ini merupakan Politikus Golkar 
yang menjabatKetua Umum Partai Golkar.

3.) Majas Apofasis adalah majas yang menegaskan sesuatu dengan cara seolah-olah menyangkal yang ditegaskan. Contohnya pada kutipanberikut

Setnov mengaku senang diperiksa KPK.Bahkan dia berterima kasih kepada KPK karena dapat mengklarifikasi berbagai isu terkait kasus korupsi E-KTP.Apalagi, dia harus tinggalkan rapat paripurna untuk memenuhi panggilan KPK.

"Saya terima kasih kepada KPK, karena saya tadi ada rapat paripurna.

Dalam kalimat tersebut terlihat bahwa Setya Novanto menegaskan bahwa dia berterima kasih kepada KPK, namun kalimat selanjutnya dia seolah-olah menyangkal apa yang dikatakannya karena kalimat selanjutnya dia mengatakan bahwa tadi ada rapat paripurna.

4.) Majas Tautologi adalah majas yang terdiri dari pengulangan kata dengan menggunakan sinonimnya. Contohnya pada kutipan pernyataan Setya Novanto berikut :

Pemeriksaan ini sangat penting untuk saya bisa mengklarifikasi secara keseluruhan dan semuanya sudah saya jelaskan dan substansinya silakan saja tanya kepada penyidik," ujar Setya Novanto.

Majas Tautologi terdapat dalam kalimat keseluruhan dan semuanya dimana kedua kalimat tersebut memiliki arti dan makna yang sama.

5.) Majas Kontradiksi minus adalah majas yang berisi pernyataan yang sifatnya menyangkal hal yang telah disebutkan pada bagian sebelumnya. Contohnya pada kutipan berikut :

Namun, dia enggan mengungkapkan siapa saja anggota dewan yang terlibat dalam mega proyek tersebut.Dia berdalih baru dapat menyebutkan inisialnya saja, lantaran kasus ini tengah diproses KPK.

Majas Kontradiksi minus terdapat dalam kalimat Dia berdalih baru dapat menyebutkan inisialnya saja, dari kalimat tersebut terlihat bahwa pengacara Elza Syarif menyangkal kalimat sebelumnya karena diawal kalimat dia memberikan pernyataan bahwadia enggan mengungkapkan siapa saja anggota dewan yang terlibat dalam mega proyek tersebut. Contoh lainnya yang terdapat Majas Kontradiksi minus yaitu :

Sudah itu dulu.Nanti lagi," singkat Elza di Gedung KPK, usai mendampingi pemeriksaan Nazarudin di 
Gedung KPK, Jakarta, Selasa 27 Agustus 2013.

Dalam kutipan tersebut pada kalimat nanti lagi terlihat pengacara Elza menyangkal kalimat sebelumnya yang mengatakan Sudah itu dulu.

6.) Majas Elipsisadalah majas yang menghilangkan suatu unsur kalimat.

Dalam berita kasus korupsi E-KTP di situs liputan6.com yang termasuk majas elipsis. Contohnya pada pernyataan Basaria Panjaitan berikut :

"Sampai sekarang sudah 110 yang kita panggil," kata Wakil Ketua KPK, Basaria Panjaitan, di Jakarta, Rabu 16 November 2016.

Dalam kutipan tersebut kalimat "Sampai sekarang sudah 110 yang kita panggil" berarti dalam kalimat tersebut menghilangkan suatu unsur kalimat yaitu kalimat saksi.Seharusnya dia mengatakan"Sampai

sekarang sudah 110 saksi yang kita panggil”".

b. Tipe Interaksi

Tipe interaksidalam berita kasus korupsi E-KTP di situs liputan6.com dari jumlah pelaku atau orang-rang yang dikutip, mengarah ke dialogis karena dialogis berasal dari kata dialog yang berarti percakapan. Dalam berita kasus korupsi E-KTP terlihat bahwa ada percakapan yang bersifat terbuka dan komunikatif antara narasumber dengan wartawan. Contohnya pada kutipan berikut :

Liputan6.com, Jakarta - Komisi Pemberantasan Korupsi (KPK) pernah menyebut dugaan korupsi proyek E-KTP pada 2011-2012, sebagai kasus yang agak pelik penanganannya.Komisi

antirasuah itu pun menyisir kasus tersebut, salah satunya melalui omongan terpidana kasus korupsi Muhammad Nazaruddin.

Dari kutipan diatas kalimat yang menyatakan adanya percakapan yaitu bahwa Komisi Pemberantasan Korupsi (KPK) pernah menyebut dugaan korupsi proyek E-KTP pada 2011-2012, sebagai kasus yang agak pelik penanganannya. Peneliti mengatakan bahwa kalimat tersebut adalah hasil dari percakapan karena dari kalimat tersebut bisa kita lihat yang menjadi narasumber adalah KPK. Dan yang bertanya adalah wartawan, wartawan tidak akan menuliskan kalimat tersebut kalau mereka tidak bertanya dahulu kepada KPK mengenai kasus korupsi E-KTP ini. Peneliti juga mengatakan bahwa percakapan tersebut bersifat terbuka karenaseluruh isi dari berita kasus korupsi E-KTP di situs liputan6.comterlihat bahwa KPK terbuka kepada wartawan dengan menjelaskan apa yang terjadi dengan kasus tersebut dan siapa saja yang menjadi saksi dan tersangka.

c. Medium 
Dalam berita kasus korupsi EKTP di situs liputan6.comsarana yang digunakan adalah tulisan.Tulisan digunakan bertujuan agar pembaca dapat membaca berulang-ulang berita tersebut dan dapat lebih memahami isi dari berita karena kalau menggunakan sarana lisan jika pembaca tidak mendengar dengan jelas apa yang disampaikan maka tidak bisa menyuruh orang tersebut untuk mengulang apa yang dikatakannya, dan kalau menggunakan isyarat tidak semua pembaca bisa memahami isyarat tersebut.

d. Saluran

Saluran berkaitan dengan bagaimana teks itu dapat diterima yaitu, vonis, grafis, dan visual. Saluran yang digunakan berupa visual, karena visual adalah rangkaian proses penyampaian informasi atau pesan yang hanya terbaca oleh indera penglihatan. Dalam berita kasus korupsi E-KTP di situs liputan6.com informasi yang disampaikan yaitu berupa tulisan yaitu tulisan berita "menyisir jejak kasus korupsi E-KTP dari nyanyian Nazaruddin" yang dapat dilihat di situs liputan6.com.

e. Modus Retoris

Dalam berita kasus korupsi EKTP di situs liputan6.commodus retoris atauretorikanya bersifat persuasif karena bertujuan untuk mempengaruhi sikap pembaca atau masyarakat agar dapat tertarik untuk selalu mengikuti berita ini.Karena dilihat dari kata-kata yang digunakan seperti kata pelik, rumit,megadan kasus yang besar, dari kata-kata tersebut liputan6.com ingin memberitahu bahwa kasus ini merupakan kasus korupsi yang sulit untuk ditangani dan merupakan kasus yang besar yang tengah ditangani KPK.

\section{PEMBAHASAN}

Berdasarkan teori yang peneliti gunakan, yaitu teori semiotika sosial menurut MAK Halliday, untuk mengetahui medan wacana, pelibat wacana, dan sarana wacana dari berita kasus korupsi E-KTP di situs liputan6.com. Dari hasil penelitian diatas maka pembahasannya yaitu :

\section{Medan Wacana}

Dapat dilihat dari hasil penelitian diatas bahwa yang dijadikan wacana oleh situs liputan6.com adalah KPK yang menyelidiki kasus korupsi EKTP dari perkataan Nazaruddin, dalam berita tersebut liputan6.com menjelaskan bahwa KPK juga telah memeriksa beberapa saksi untuk menyelidiki kasus ini. Dalam Medan Wacana ada beberapa hal yang perlu diungkap yaitu :

a. Ranah Pengalaman

Dilihat dari hasil penelitian diatas maka dapat disimpulkan bahwa dari ranah pengalaman atau yang melatarbelakangi berita ini adalah adanya pengungkapan dari Nazaruddin bahwa ada penggelembungan dana proyek EKTP tahun 2011-2012.

b. Tujuan jangka pendek dari berita ini adalah agar pembaca dapat lebih memahami bahwa KPK menyelidiki kasus ini dari perkataan Nazaruddin dan agar pembaca atau masyarakat dapat mengetahui bahwa kasus korupsi E-KTP ini merupakan kasus yang 
pelik atau rumit yang sedang ditangani oleh KPK.

c. Tujuan jangka panjangnya yaitu agar pembaca atau masyarakat bisa terus menerus melihat atau membaca berita kasus korupsi EKTPkapan saja dan dimana saja karena berita ini diletakkan di media online atau situs.

\section{Pelibat Wacana}

Yang dijadikan pelibat atau atau orang-orang yang dikutip dalam berita di situs liputan6.com adalah Muhammad Nazaruddin, Setya Novanto, Febri Diansyah, Sugiharto, Ganjar Pranowo, Markus Nari, Chairuman Harahap, Junaidi, Elza Syarif, Basaria Panjaitan, dan Irman. Dalam pelibat wacana ada beberapa hal yang perlu diketahui yaitu :

a. Peran

Orang-orang tersebut dikutip dalam pemberitaan karena beberapa diantara mereka seperti, Muhammad Nazaruddin, Setya Novanto, Ganjar Pranowo, Markus Nari, Chairuman Harahap, dan Junaidi kedudukan atau peran mereka adalah sebagai saksi dalam kasus ini.Sedangkan Sugiharto, dan Irman perannya adalah tersangka.Febri Diansyah dan Basaria Panjaitan perannya adalah sebagai juru bicara KPK dan wakil ketua KPK.Elza Syarif perannya adalah pengacara dari Nazaruddin yang mengungkap siapa saja yang terlibat dalam kasus ini.

b. Status sosial

Nazaruddin status sosialnya adalah mantan anggota komisi II DPR 2009-2014 dan juga tersangka kasus suap Hambalang dan didakwa gratifikasi dan pencucian uang melalui perusahaan miliknya.Setya Novanto dahulu anggota komisi II
DPR sekarang menjadi ketua DPR dan ketua umum partai Golkar.Irman status sosialnya adalaheks Direktur Jenderal Kependudukan dan Pencatatan Sipil (Dukcapil) Kemendagri dan sekarang tersangka kasus korupsi E-KTP sedangkan Sugiharto adalah pejabat pembuat komitmen (PPK) Direktur Pengelola Informasi Administrasi Kependudukan Ditjen Dukcapil Kemendagri.Selanjutnya Markus Nari status sosialnya adalah anggota komisi II DPR dan fraksi partai Golkar.Chairuman Harahap mantan ketua komisi II DPR dan Junaidi status sosialnya adalah PNS Kementerian Dalam Negeri.Febri Diansyah dan Basaria Panjaitan adalah juru bicara KPK dan wakil ketua KPK.Terakhir adalah Elza Syarif adalah seorang pengacara yang juga merupakan pengacara dari Nazaruddin.

c. Jarak Sosial

Dari hasil penelitian dapat dilihat bahwa ada jarak antara pelibat seperti Nazaruddin, Ganjar Pranowo, Setya Novanto dan Markus Nari, ada jarak anatara mereka karena berasal dari partai yang berbeda dan ada pula hubungan karena mereka semua pernah menjadi anggota komisi II DPR sama seperti Chairuman Harahap. Bukan hanya itu tetapi ada pula hubungan antara pelibat lainnya seperti Irman, Junaidi dan Sugiharto yang sama-sama bekerja di Kemendagri dan Irman merupakan bekas atasan langsung Sugiharto.Elza Syarif dan Nazaruddin juga mempunyai hubungan karena Elza Syarif adalah pengacara dari Nazaruddin.Pelibat selanjutnya 
yang mempunyai hubungan yaitu Febri Diansyah dan Basaria Panjaitan merupakan sma-sama penyidik KPK yang juga menyelidiki kasus korupsi E-KTP.

\section{Sarana Wacana}

Dalam sarana wacana ada lima hal yang perlu diketahui adalah :

a. Peran Bahasa

Dalam kasus korupsi E-KTP disitus liputan6.com terdapat beberapa gaya bahasa atau majas yaitu, Majas Eufisme, Majas Aptronim, Majas Apofasis, Majas Tautologi, Majas kontradiksi interminus, dan Majas Elipsis.

b. Tipe Interaksi mengarah ke dialogis karena dalam kalimat di berita kasus korupsi E-KTP di situs liputan6.com terdapat beberapa penulisan kalimat yang ditulis dari hasil percakapan antara narasumber seperti KPK dengan wartawan dan pelibat dengan wartawan.

c. Medium yang digunakan adalah tulisan karena berita dibuat dalam bentuk teks.

d. Saluran yang digunakan adalah visual karena informasi yang disampaikan dapat dilihat di situs liputan6.com.

e. Modus Retoris atau retorika yang digunakan bersifat persuasif yang bertujuan mempengaruhi sikap pembaca dan masyarakat.

\section{PENUTUP}

\section{Kesimpulan}

Berdasarkan analisis dari hasil penelitian skripsi yang telah peneliti paparkan pada berita tanggal 14 Desember 2016 tentang "Menyisir Jejak Korupsi E-KTP Dari Nyanyian Nazaruddin" dengan menggunakan metode semiotika sosial MAK Halliday. Maka peneliti dapat menarik hasil penelitiannya yaitu memaknai isi teks yang diproduksi oleh liputan6.com dalam berita kasus korupsi E-KTP menunjukkan bahwa

1. Medan Wacana dalam analisis membahas tiga ulasan yaitu ranah pengalaman, tujuan jangka pendek dan tujuan jangka panjang. Ranah pengalaman yaitu adanya pengungkapan Nazaruddin tentang adanya aliran dana dan penggelembungan dana proyek E-KTP tahun 2011-2102. Tujuan jangka pendek yaitu agar masyarakat dapat mengetahui bahwa kasus ini adalah kasus besar yang tengah ditangani KPK. Tujuan jangka panjang adalah masyarat dapat melihat berita kasus ini kapan saja karena berita ini ada di situs liputan6.com.

2. Pelibat Wacana membahas tiga hal yaitu, peran status, dan jarak sosial. Peran yang dikutip atau berperan dalam berita kasus korupsi E-KTP di disitus liputan6.com adalah Nazaruddin, Setya Novanto, Febri Diansyah, Sugiharto, Ganjar Pranowo, Markus Nari, Chairuman Harahap, Junaidi, Elza Syarif, Basaria Panjaitan, dan Irman. Status pelibat tersebut dikutip dalam berita tersebut karena mereka berperan sebagai saksi, tersangka, juru bicara dan pengacara. Jarak sosial adalah ada diantara pelibat seperti Nazaruddin, Setya Novanto, Ganjar Pranowo, Chairuman Harahap, dan Markus Nari pernah bekerja sama menjadi anggota komisi II DPR. Irman, Sugiharto, dan Junaidi sama- 
sama bekerja di Kemendagri. Febri Diansyah dan Basaria Panjaitan adalah juru bicara KPK. Elza syarif adalah pengacara Nazaruddin.

3. Sarana Wacana membahas lima hal yaitu, Peran Bahasa penggunaan gaya bahasa yang digunakan dalam berita kasus korupsi E-KTP adalah Majas Eufisme, Majas Aptronim, Majas Apofasis, Majas Tautologi, Majas Kontradiksi Minus Dan Majas Elipsis. Tipe Interaksi adalah dialogis karena ada kalimat yang ditulis berasal dari percakapan antara KPK, Pelibat dan Wartawan. Medium yang digunakan dalam menulis berita kasus korupsi E-KTP adalah tulisan. Saluran berupa visual karena informasi di buat dalam bentuk tulisan dan hanya dapat dilihat oleh indera penglihatan. Modus Retoris yang digunakan bersifat persuasif yang bertujuan mempengaruhi sikap pembaca agar terus mengikuti berita kasus korupsi di E-KTP di situs liputan6.com.

\section{Saran}

1. Disarankan

untuk

Liputan6.com

kedepannyadalam menuliskan berita hendaknya dapat menggunakan kata-kata yang mudah dimengerti oleh seluruh masyarakat dan pembaca.

2. Bagi mahasiswa Fakultas IlmuIlmu Sosial Jurusan Ilmu Komunikasi Universitas Dehasen Bengkulu yang penelitiannyasama mungkin dapat menjadikan skripsi ini sebagai bahan referensi dan rujukan dalam penelitiannya.
Jika mahasiswa ingin melakukan penelitian selanjutnya dengan melihat berita di Liputan6.com dapat menggunakan metode analisis wacana untuk mengetahui lebih kritis atau mendalam tentang struktur bahasa dalam berita tersebut.

3. Peneliti berharap untuk seluruh masyarakat sebagai penikmat berita agar selalu mengikuti atau memantau berita kasus korupsi E-KTP ini agar kasus ini bisa terselesaikan.

\section{DAFTAR PUSTAKA}

Ardianto, $\quad$ Elvinaro. 2004. Komunikasi Massa Suatu Pengantar. Bandung: Simbiosa Rekatama Media

Agung, Gregorius. 2000. Membuat Homepage Interaktif Dengan CGI/Perl. Jakarta: PT. Elex Media Koputindo.

Arikunto, Suharsimi. 2002.

Metodologi Penelitian.

Jakarta : PT. Rineka cipta

Charnley, Mitchel V. Reporting Journalist.1975. New York

Halliday,M A K dan Hasan, Ruqaiya.1994. Bahasa,

Konteks Dan Teks, AspekAspek Bahasan Dalam Pandangan Semiotika Sosial. Yogyakarta :

Gadjahmada University

Kurniawan,Agung. 2005.

Transformasi Pelayanan Publik.

Yogyakarta: Pembaharuan.

Moleong, Lexy J. 2007.

Metode Penelitian Kualitatif.

Bandung : Rosdakarya. 
Rivers, William L. 2004. Media Massa dan Masyarakat Modern. Jakarta : Kencana

Romli, Asep Syamsul M. 2012. Jurnalistik Online : Panduan Praktis Mengelola Media

Online. Bandung : Nuansa Cendikia

Rusmana,Dadan.2014. Filsafat Semiotika: Paradigm Teori, DanMetode

Interprestasi Tanda Dari Semiotika Structural Hingga Dekonstruksi praktis. Bandung: CV Pustaka setia.

Sarwono, Jonathan. 2006. Metode Penelitian Kuantitatif dan Kualitatif. Yogyakarta : Graha Ilmu

Saragih,Amrin. 2006. Bahasa Dalam Konteks Sosial: Pendekatan Linguistik Fungsional Sistematik Tata Bahasa Dan Wacana. Medan : Program Pasca Sarjana USU.

Soehoet, A.M Hoeta. 2003. Dasar Dasar Jurnalistik, Yayasan Kampus Tercinta, Jakarta : IISIP

Sobur,Alex.2002. Analisis Teks Media: Suatu Pengantar Untuk AnalisisWacana, Analisis Semiotik, Analisis Framing. Bandung: PT Remaja Rosdakarya

Suryawati, Indah. 2011. Jurnalistik : Suatu Pengantar Teori dan Praktek. Bogor :Ghalia Indonesia.

Sumadiria, Haris. 2005.Jurnalistik Berita - Menulis Berita dan Feature. Bandung: Simbiosa Rekatama Media

Tinarbuko,Sumbo. 2008. Semiotika Komunikasi Visual. Yogyakarta. Jalan Sutra
Zaenuddin,HM. 2011. The Journalist (edisi revisi). Jakarta : Simbiosa Rekatama Media

\section{Jurnal Penellitian}

Agustin, Ika Suci. 2014. Analisis Semiotika Sosial Pemberitaan Pernikahan Beda Agama Pada Asmirandah Dengan Jonas Rivanno di Situs Tempo.Co. Skripsi.Jakarta :Universitas Islam Negeri Syarif Hidayatullah

Hariyanto. 2015. Analisis Framing Pemberitaan Kasus Korupsi Ratu Atut Di Media Online Mediaindonesia.Com Dan Viva.Co.Id

\section{Internet}

www.e-ktp.com

www.kpk.com

www.liputan6.com

Foto Berita :
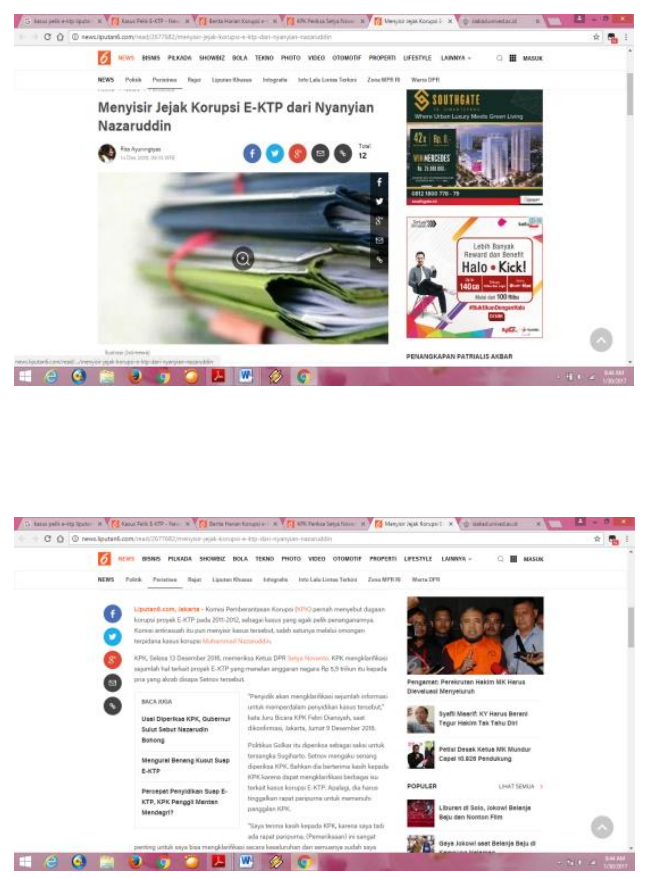

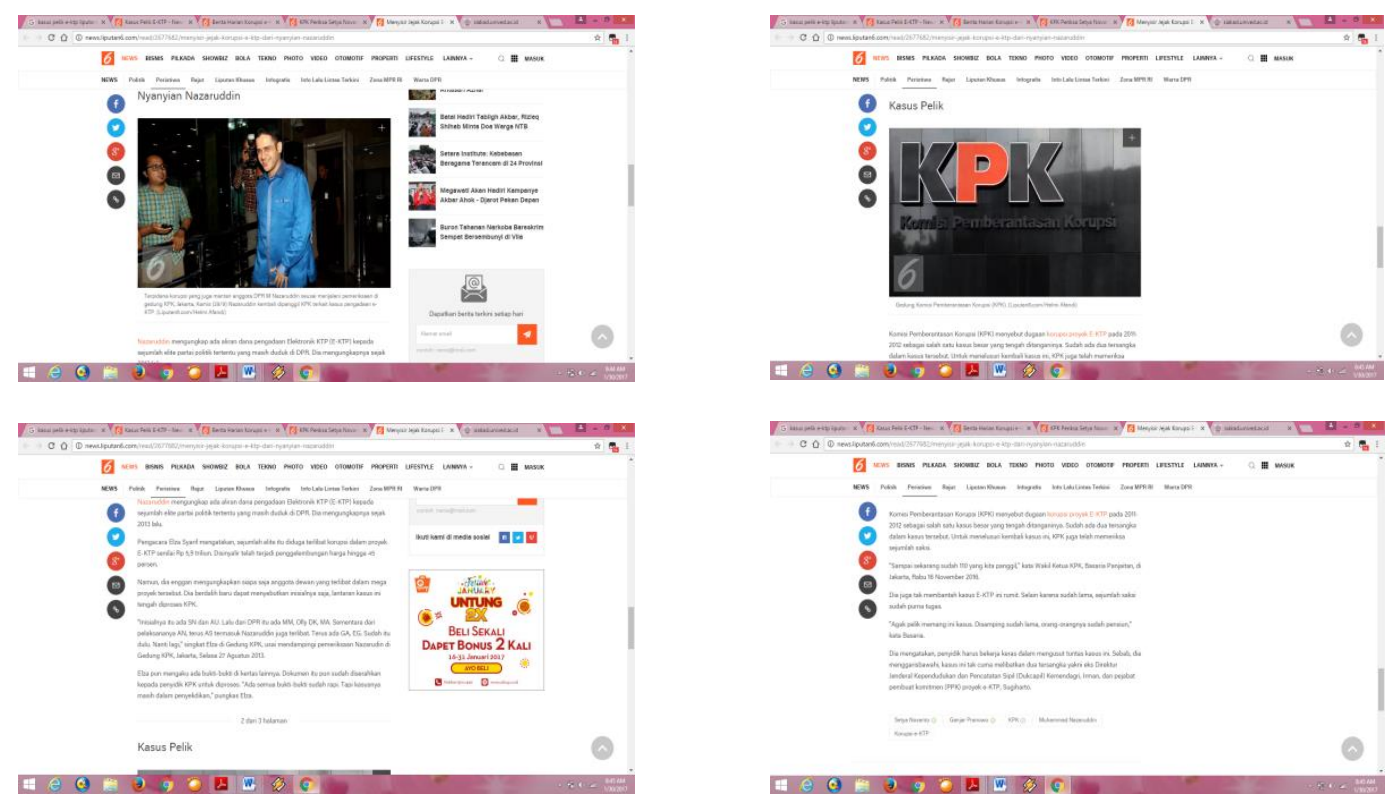